\title{
Pnictides as Symmetrically Bridging Ligands in Novel Neutral Complexes Manfred Scheer, ${ }^{[\text {[a] }}$ Jan Müller, ${ }^{\text {[a] }}$ Michael Schiffer, ${ }^{\text {[a] }}$ Gerhard Baum, ${ }^{\text {[a] }}$ and Rainer Winter ${ }^{[\mathrm{b}]}$
}

\begin{abstract}
The reaction of [LWCl] (3) $\left[\mathrm{L}=\mathrm{N}\left(\mathrm{CH}_{2} \mathrm{CH}_{2} \mathrm{NiPr}\right)_{3}\right]$ with $\mathrm{LiE}\left(\mathrm{SiMe}_{3}\right)_{2}$ $(\mathrm{E}=\mathrm{P}, \mathrm{As}, \mathrm{Sb})$ yields the novel, neutral pnictido-bridged complexes $[\mathrm{LW}=\mathrm{E}=\mathrm{WL}](5-7)$. By following the reaction, which starts from the LiP$\left(\mathrm{SiMe}_{3}\right)_{2}$ derivative, by ${ }^{31} \mathrm{P} \mathrm{NMR}$ spectroscopy, the formation of an intermediate with a terminal pnictido ligand can be ruled out. The paramagnetic complexes 5-7 are comprehensively spec-
\end{abstract}

troscopically characterised. The X-ray structure analysis of the heterocumulenes 5-7 reveals a linear structure in which the two W-"tren" units bind to the central pnictido atom in a staggered conformation ["tren" $=$ tren- based ligand; tren $=$ tris (2-aminoethyl)amine. When $\mathrm{N}_{2}$ is used as the inert gas in the synthesis of the starting material $\left[\left\{\mathrm{N}\left(\mathrm{CH}_{2} \mathrm{CH}_{2} \mathrm{NNp}\right)_{3}\right\} \mathrm{WCl}\right]\left[\mathrm{Np}=\mathrm{CH}_{2} \mathrm{C}-\right.$ $\left.\left(\mathrm{CH}_{3}\right)_{3}\right]$, the complex $\left[\left\{\left[\mathrm{N}\left(\mathrm{CH}_{2} \mathrm{CH}_{2}\right.\right.\right.\right.$ $\left.\left.\left.\mathrm{NNp})_{3}\right] \mathrm{W}\right\}_{2}\left(\mu, \eta^{1}: \eta^{1}-\mathrm{N}_{2}\right)\right](4)$ is formed as a side product. Complex 4 possesses a hydrazido $(4-)\left(\mathrm{N}_{2}{ }^{4-}\right)$ ligand connected by two tungsten-"tren" moieties.

\section{Introduction}

A small number of complexes are known which contain pnictido ligands $\mathrm{E}^{3-}$ of the heavier Group 15 elements $(\mathrm{E}=\mathrm{P}$, $\mathrm{As}, \mathrm{Sb}, \mathrm{Bi})^{[1]}$ and which have the low coordination numbers (CN) 1 and 2. Recently complexes of type $\mathbf{A}^{[2]}$ with a terminal

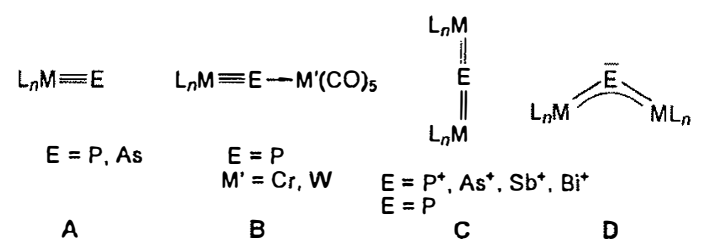

ligand and $\mathrm{CN} 1$ were synthesised and structurally characterised, for example, $\left[\left(\mathrm{Ar}^{\prime} \mathrm{RN}\right)_{3} \mathrm{Mo} \equiv \mathrm{P}\right]\left(\mathrm{Ar}^{\prime}=3,5-\mathrm{Me}_{2} \mathrm{C}_{6} \mathrm{H}_{3}, \mathrm{R}=\right.$ $\left.\mathrm{C}\left(\mathrm{CD}_{3}\right)_{2} \mathrm{CH}_{3}\right)^{[3]}$ and $\left[\left(\mathrm{N}_{3} \mathrm{~N}\right) \mathrm{M}=\mathrm{E}\right]\left\{\mathrm{E}=\mathrm{P}^{[4]}(\mathbf{1}), \mathrm{M}=\mathrm{W}, \mathrm{Mo}\right.$; $\mathrm{N}_{3} \mathrm{~N}=\mathrm{N}\left(\mathrm{CH}_{2} \mathrm{CH}_{2} \mathrm{NSiMe}_{3}\right)_{3} ; \mathrm{E}=\mathrm{As}$ (2), $\left.\mathrm{M}=\mathrm{W}^{[5]}, \mathrm{Mo}^{[6]}\right\}$.

[a] Prof. Dr. M. Scheer, Dr. J. Müller, Dipl.-Chem. M. Schiffer, G. Baum Institut für Anorganische Chemie der Universität Karlsruhe 76128 Karlsruhe (Germany)

Fax: (+49) 721-661921

E-mail: mascheer@achibm6.chemie.uni-karlsruhe.de

[b] Dr. R. Winter

Institut für Anorganische Chemie der Universität Stuttgart Pfaffenwaldring 55, 70569 Stuttgart (Germany)

Fax: (+49)711-6854165

E-mail: winter@iac.uni-stuttgart.de
Only lately has the asymmetric, linear coordination-mode B with $\mathrm{CN} 2$ been found as well in the complexes $\left[\left(\mathrm{N}_{3} \mathrm{~N}\right) \mathrm{M} \equiv \mathrm{E} \rightarrow \mathrm{ML}_{m}\right] \quad\left[\mathrm{ML}_{m}=\mathrm{GaCl}_{3} ; ;^{[7]} \mathrm{M}(\mathrm{CO})_{4}, \quad \mathrm{M}=\mathrm{Cr}\right.$, $\left.\mathrm{W}^{[5]}\right]$ and $\left[(\right.$ thf $\left.)(\mathrm{RO})_{3} \mathrm{~W} \equiv \mathrm{P} \rightarrow \mathrm{M}^{\prime}(\mathrm{CO})_{5}\right]\left[\mathrm{M}^{\prime}=\mathrm{Cr}, \mathrm{W} ; \mathrm{R}=2,5-\right.$ $\left.\mathrm{Me}_{2} \mathrm{C}_{6} \mathrm{H}_{3},{ }^{[8]} t \mathrm{Bu}^{[9]}\right]$. Symmetrical linearly bridged complexes of type $\mathbf{C}$ of the heavier Group 15 elements have so far been described exclusively as cationic complexes by Huttner and co-workers. ${ }^{[10]}$ Neutral compounds of this type are only known for $\mathrm{E}=\mathrm{P}$ in the complexes $\left[\left\{\mathrm{Cp}_{2} \mathrm{Zr}\right\}_{2}(\mu-\mathrm{P})\right]$ and $\left[\left\{\left(\mathrm{R}^{\prime} \mathrm{RN}\right)_{3} \mathrm{Mo}\right\}_{2}(\mu-\mathrm{P})\right]\left(\mathrm{R}=\mathrm{Ph} ; \mathrm{R}^{\prime}=t \mathrm{Bu}\right)$ synthesised by Stephan $^{[11]}$ and Cummins ${ }^{[12]}$, respectively. The bent coordination mode $\mathbf{D}$, however, has not yet been observed for the heavier Group 15 elements ${ }^{[1]}$; with the exception of nitrogen ${ }^{[13 a-c]}$ and first example for phosphorus. ${ }^{[13 \mathrm{~d}]}$

We have shown that one possibility to synthesise the pnictido complexes $\mathbf{1}$ and $\mathbf{2}$ is to start from $\mathrm{Li}\left[\mathrm{E}\left(\mathrm{SiMe}_{3}\right)_{2}\right](\mathrm{E}=$ $\mathrm{P}, \mathrm{As})$ as shown in Equation (1); however, the reaction of

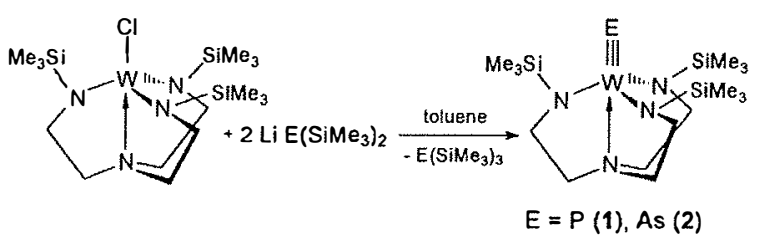

$\mathrm{Li}\left[\mathrm{Sb}\left(\mathrm{SiMe}_{3}\right)_{2}(\mathrm{dme})\right]$ with $\left[\left\{\mathrm{N}\left(\mathrm{CH}_{2} \mathrm{CH}_{2} \mathrm{NSiMe}_{3}\right)_{3}\right] \mathrm{WCl}\right] \operatorname{did}$ not occur irrespective of the reaction conditions used. Evidently, the steric demand of the $\mathrm{SiMe}_{3}$ groups in the 
tungsten complex inhibits the substitution of the $\mathrm{Cl}$ atom by the $\mathrm{Sb}$ moiety. The use of a sterically less bulky tris-(2-

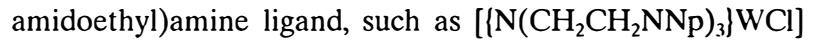
$\left[\mathrm{Np}=\mathrm{CH}_{2} \mathrm{C}\left(\mathrm{CH}_{3}\right)_{3}\right]$, however, enables the $\mathrm{W}-\mathrm{Sb}$ bond formation to take place, but a product with a terminal antimonido ligand is not obtained. Owing to a further intermolecular $\mathrm{Sb}-\mathrm{W}$ bond formation, an Sb-bridged neutral heterocumulene of type $\mathbf{C}$ is formed. ${ }^{[14]}$ Herein we verify that this reaction method is generally extendible for the synthesis of the entire series of neutral heterocumulene complexes of the heavier Group 15 elements.

\section{Results and Discussion}

Synthesis and crystal structure of the starting material: The starting material $\left[\left\{\mathrm{N}\left(\mathrm{CH}_{2} \mathrm{CH}_{2} \mathrm{NiPr}\right)_{3}\right\} \mathrm{WCl}\right](3)$ was synthesised by the reaction of $\left[\mathrm{WCl}_{4}(\mathrm{dme})\right]$ with $\mathrm{Li}_{3}\left[\mathrm{~N}\left(\mathrm{CH}_{2} \mathrm{CH}_{2}\right.\right.$ $\mathrm{NiPr})_{3}$ ]. It is a brown crystalline compound and the molecular ion peak is observed in the mass spectrum; paramagnetic shifts in the ${ }^{1} \mathrm{H}$ NMR spectrum are also observed as expected for a $\mathrm{d}^{2}$ complex.

The X-ray structure of compound 3 shows a distorted $C_{3}$ symmetric molecule in a trigonal-bipyramidal arrangement along the central tungsten atom (Figure 1 ). The $\mathrm{W}-\mathrm{Cl}$ bond [2.407(2) $\AA$ ] is slightly longer than those found for the chloro

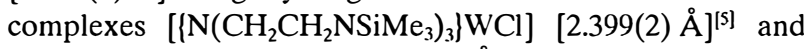
$\left[\left\{\mathrm{N}\left(\mathrm{CH}_{2} \mathrm{CH}_{2} \mathrm{NNp}\right)_{3}\right\} \mathrm{WCl}\right][2.389(2) \AA] \cdot \cdot^{[13]}$

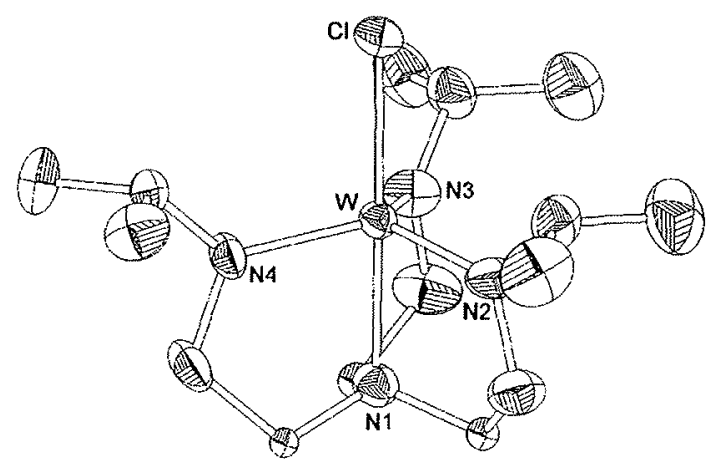

Figure 1. Molecular structure of $\left[\left\{\mathrm{N}\left(\mathrm{CH}_{2} \mathrm{CH}_{2} \mathrm{NiPr}\right)_{3}\right\} \mathrm{WCl}\right]$ (3) (ellipsoids drawn at of $50 \%$ probability level). Only one position of the distorted neighbour $\mathrm{C}$ atoms on the axial $\mathrm{N} 1$ atom is shown for clarity. Selected bond lengths $[\AA]$ and angles $\left[{ }^{\circ}\right]: \mathrm{W}-\mathrm{Cl} 2.407(2), \mathrm{W}-\mathrm{N} 12.173(9), \mathrm{W}-\mathrm{N} 21.967(9)$, W-N3 1.969(9), W-N4 1.963(8), N1-W-Cl 179.5(2), N1-W-N2 81.2(4), N1W-N3 81.0(4), N1-W-N4 81.3(3), Cl-W-N2 99.2(3), Cl-W-N4 98.2(3), N2-WN3 117.8(4), N3-W-N4 117.4(4).

It is important to carry out the reaction in Equation (1) under an atmosphere of argon, otherwise $\mathrm{N}_{2}$ complexes are obtained. Hence, during the synthesis of $\left[\left\{\mathrm{N}\left(\mathrm{CH}_{2} \mathrm{CH}_{2} \mathrm{NNp}\right)_{3}\right\}-\right.$ $\mathrm{WCl}]^{[14]}$ under $\mathrm{N}_{2}$, the complex $\left[\left\{\left[\mathrm{N}\left(\mathrm{CH}_{2} \mathrm{CH}_{2} \mathrm{NNp}\right)_{3}\right] \mathrm{W}\right\}_{2^{-}}\right.$ $\left.\left(\mu, \eta^{1}: \eta^{1}-\mathrm{N}_{2}\right)\right](4)$ is formed as a side product. The molecular structure of 4 (Figure 2) reveals a hydrazido(4-) $\left(\mathrm{N}_{2}{ }^{4-}\right)$ ligand connected by two tungsten-"tren" moieties ["tren" = trenbased ligand; tren $=$ tris-(2-aminoethyl)amine] and is characterised by a linear N2-W1-N1-N1'-W1'-N2' axis. The N1-N1' bond length $[1.39(2) \AA]$ is on the upper limit of those

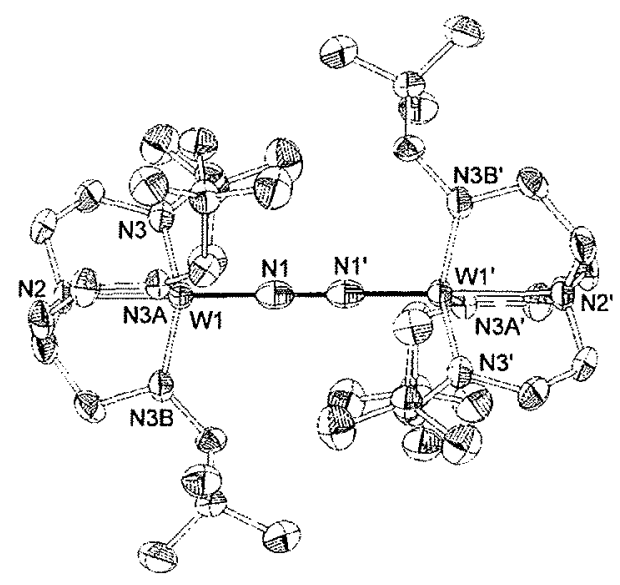

Figure 2. Molecular structure of $\left[\left[\left[\mathrm{N}\left(\mathrm{CH}_{2} \mathrm{CH}_{2} \mathrm{NNp}\right)_{3}\right] \mathrm{W}\right]_{2}\left(\mu, \eta^{1}: \eta^{1}-\mathrm{N}_{2}\right)\right](4)$ (ellipsoids drawn at of $50 \%$ probability level, all $\mathrm{H}$ atoms have been omitted for clarity). Selected bond lengths $[\AA]$ and angles $\left[{ }^{\circ}\right]: \mathrm{N} 1-\mathrm{N} 1{ }^{\prime}$ 1.39(2), W1-N1 1.845(11), W1-N2 2.304(9), W1-N3 1.983(6), N1-W1-N2 180.0, N1-W1-N3 101.5(2), N3-W1-N3B 116.10(10), N2-W1-N3 78.5(2).

found in other hydrazido complexes. ${ }^{[15]}$ In the isostructural molybdenum complex $\left[\left\{\left[\mathrm{N}\left(\mathrm{CH}_{2} \mathrm{CH}_{2} \mathrm{NSiMe}_{2} t \mathrm{Bu}\right)_{3}\right]\right.\right.$ $\left.\mathrm{Mo}_{2}\left(\mu, \eta^{1}: \eta^{1}-\mathrm{N}_{2}\right)\right]$ this bond is significantly shorter $[1.20(2) \AA] .^{[16]}$

Synthesis of the heterocumulenes: Thermolysis of $\left[\left\{\mathrm{N}\left(\mathrm{CH}_{2} \mathrm{CH}_{2} \mathrm{NiPr}\right)_{3}\right\} \mathrm{WCl}\right](3)$ and $\left[\mathrm{LiE}\left(\mathrm{SiMe}_{3}\right)_{2}\right](\mathrm{E}=\mathrm{P}, \mathrm{As}$, $\mathrm{Sb}, \mathrm{Bi}$ ) in toluene for $48 \mathrm{~h}$ at $100^{\circ} \mathrm{C}$ yields the heterocumulene complexes $\left[\left\{\left[\mathrm{N}\left(\mathrm{CH}_{2} \mathrm{CH}_{2} \mathrm{NiPr}\right)_{3}\right] \mathrm{W}\right\}_{2}(\mu\right.$-E)] (5-7) [Eq. (2)]. Instead of terminal pnictido complexes, symmetrically E-bridged complexes are formed; these are the first neutral

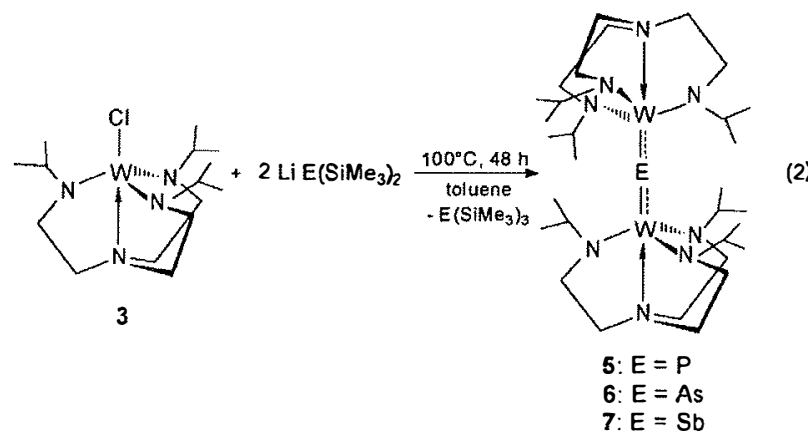

As- and the second Sb-containing examples of this class of compounds. Attempts to isolate the corresponding $\mathrm{Bi}$ compound have failed so far. However, the existence of such a product in the crude reaction mixture could be determined by ${ }^{1} \mathrm{H}$ NMR spectroscopy. The observed data show the correct tendency of the chemical shifts in the series starting from phosphorus and going to the heavier congeners. ${ }^{[17]}$

The speculations about the possible pathways for the formation of the heterocumulenes 5-7 are presented in Scheme 1. Schrock was able to show that the formation of the phosphido complex $\left[\left(\mathrm{N}_{3} \mathrm{~N}\right) \mathrm{M} \equiv \mathrm{P}\right] \quad\left(\mathrm{N}_{3} \mathrm{~N}=\right.$ $\left.\mathrm{N}\left(\mathrm{CH}_{2} \mathrm{CH}_{2} \mathrm{NSiMe}_{3}\right)_{3}, \mathrm{M}=\mathrm{Mo}, \mathrm{W}\right)$ by the reaction of 


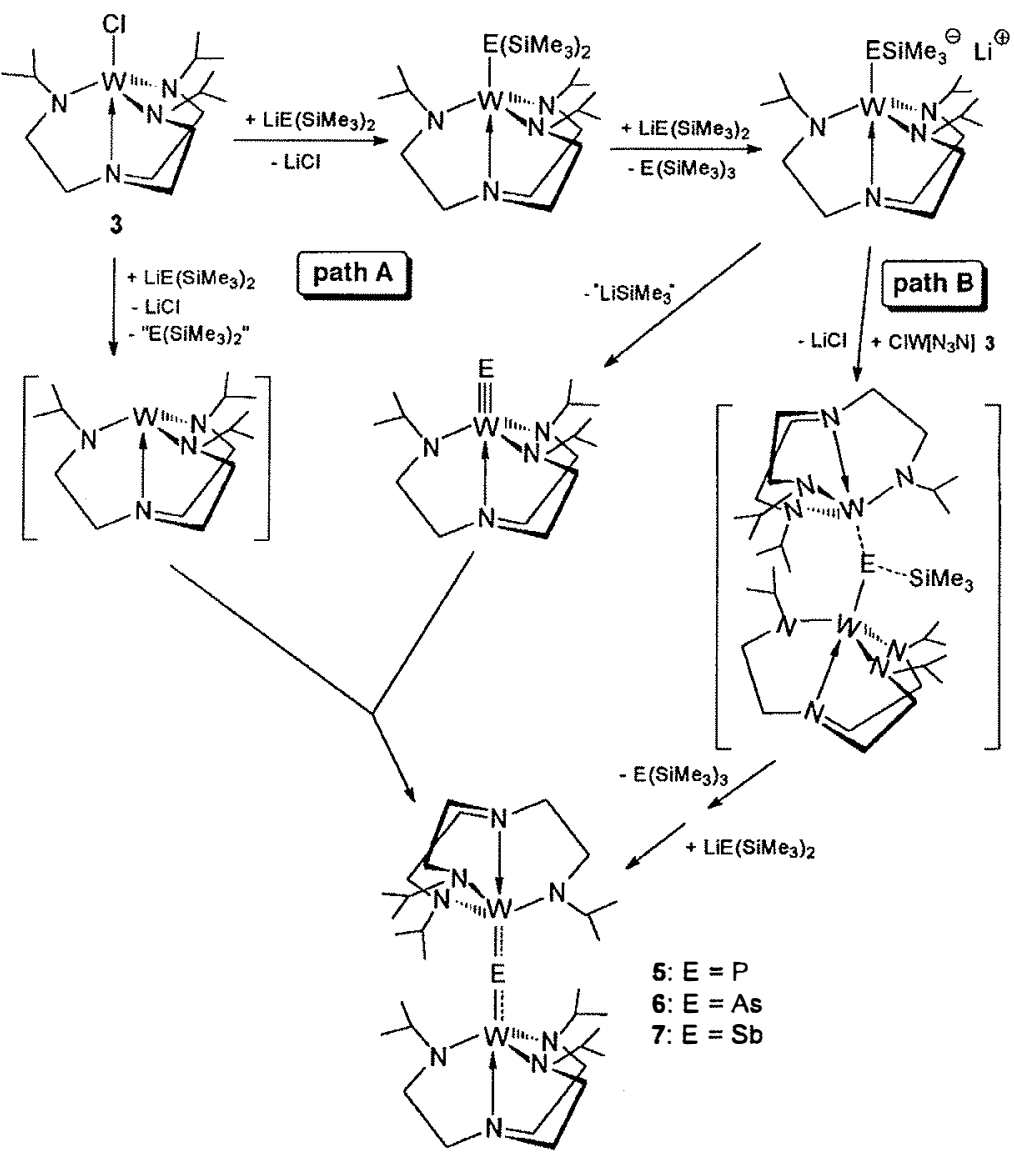

Scheme 1. Proposed reaction pathways of the reaction of $\left[\mathrm{N}\left(\mathrm{CH}_{2} \mathrm{CH}_{2} \mathrm{NiPr}\right)_{3} \mathrm{WCl}\right]$ (3) with $\mathrm{LiE}\left(\mathrm{SiMe}_{3}\right)_{2}$ $(\mathrm{E}=\mathrm{P}, \mathrm{As}, \mathrm{Sb})$.

$\left[\left(\mathrm{N}_{3} \mathrm{~N}\right) \mathrm{MCl}\right]$ with LiPPhH occurs via a phosphanido complex $\left[\left(\mathrm{N}_{3} \mathrm{~N}\right) \mathrm{M}-\mathrm{PHPh}\right]$, which could be isolated; this intermediate reacts with $\mathrm{LiPHPh}$ or $\mathrm{LiR}$ to form the product. ${ }^{[6]}$ Therefore, the first step of the reaction in Equation (2) should be the creation of an intermediate of the formula $\left[\left\{\mathrm{N}\left(\mathrm{CH}_{2} \mathrm{CH}_{2} \mathrm{NiPr}\right)_{3}\right\} \mathrm{W}-\mathrm{E}\left(\mathrm{SiMe}_{3}\right)_{2}\right]$ after $\mathrm{Cl}$ substitution within 3. After subsequent metalation with a second equivalent of $\mathrm{LiE}\left(\mathrm{SiMe}_{3}\right)_{2} \quad(\mathrm{E}=\mathrm{P}, \mathrm{As}, \mathrm{Sb})$ two further pathways are imaginable. Firstly (path $\mathbf{A}$ ), the formation of the originally desired pnictido complex $\left[\left\{\mathrm{N}\left(\mathrm{CH}_{2} \mathrm{CH}_{2} \mathrm{NiPr}\right)_{3}\right\} \mathrm{W} \equiv \mathrm{E}\right]$, which subsequently reacts with an unsaturated $\mathrm{d}^{3}$-tungsten complex $\left[\left\{\mathrm{N}\left(\mathrm{CH}_{2} \mathrm{CH}_{2} \mathrm{NiPr}\right)_{3}\right\} \mathrm{W}\right]$ that arises from a possible $\mathrm{Cl}$ elimination of $\mathbf{3}$ by the base. Such a pathway was described by Cummins et al.; they showed that $\left[\mathrm{Mo}(\mathrm{N} t B u \mathrm{Ph})_{3}\right]$ and $\left[(\mathrm{Ph} t B u \mathrm{~N})_{3} \mathrm{Mo} \equiv \mathrm{P}\right]$ undergo a phosphorus-transfer reaction to give the $\mu-\mathrm{P}_{1}$-bridged intermediate $\left[\left\{(\mathrm{Ph} t \mathrm{BuN})_{3} \mathrm{Mo}\right\}_{2} \mathrm{P}\right]$ at low temperatures. ${ }^{[12]} \mathrm{By}$ following reaction [Eq. (2)] at $100^{\circ} \mathrm{C}$, starting from $\mathrm{LiP}\left(\mathrm{SiMe}_{3}\right)_{2}$, by ${ }^{31} \mathrm{P} \mathrm{NMR}$ (range of measurement: $\delta=1300$ to $-400 \mathrm{ppm}$ ) no evidence of a diamagnetic intermediate $\left[\left\{\mathrm{N}\left(\mathrm{CH}_{2} \mathrm{CH}_{2} \mathrm{~N} i \mathrm{Pr}\right)_{3}\right\} \mathrm{W} \equiv \mathrm{P}\right]$ was found, but an increasing content of $\mathrm{P}\left(\mathrm{SiMe}_{3}\right)_{3}$ was detected. Thus, we tend more to prefer the pathway $\mathbf{B}$, in which $\left[\left\{\mathrm{N}\left(\mathrm{CH}_{2} \mathrm{CH}_{2} \mathrm{NiPr}\right)_{3}\right\} \mathrm{W}-\mathrm{E}\left(\mathrm{SiMe}_{3}\right)\right] \mathrm{Li}$ reacts with a second molecule of 3 and through a simultaneous reduction in the presence of $\mathrm{LiE}\left(\mathrm{SiMe}_{3}\right)_{2}$, the neutral $\mu$-E-bridging complexes 5-7 are formed.
Spectroscopic properties: Compounds 5, 6 and 7 are red, green and yellow crystalline materials, respectively, that are sparingly soluble in $n$-hexane and readily soluble in toluene, $\mathrm{CH}_{2} \mathrm{Cl}_{2}$ and THF. In the mass spectra of all products, the appropriate molecular ion is observed as an intense peak. Furthermore, the spectra reveal a further intense peak that indicates the existence of a fragment of the composition $\left[\left\{\mathrm{N}\left(\mathrm{CH}_{2} \mathrm{CH}_{2} \mathrm{~N} i \mathrm{Pr}\right)_{3}\right\} \mathrm{W} \equiv \mathrm{E}\right]$ $(\mathrm{E}=\mathrm{P}, \mathrm{As}, \mathrm{Sb})$ with a terminal pnictido ligand.

In the range between +80 and $-80^{\circ} \mathrm{C}$ the ${ }^{1} \mathrm{H}$ NMR spectra of 5-7 all reveal three broad signals corresponding to paramagnetic tungsten complexes. After integration, the signals of the ethylene bridge and the methyl group of the $i \mathrm{Pr}$ ligand could be assigned. Probably, as a result of its large broadening, the signal for the $\mathrm{CH}$ group of the $i \mathrm{Pr}$ substituent is missing. In the ${ }^{31} \mathrm{P} \mathrm{NMR}$ spectrum of 5 no signal could be detected in the range of $\delta=$ 1500 to $-400 \mathrm{ppm}$. The same situation was found for the EPR measurements of the compounds at $77 \mathrm{~K}$. As theoretical studies that use the $\mathrm{BP} / \mathrm{SVP}$ approximation for the complex $\left[\left(\mathrm{N}\left(\mathrm{CH}_{2} \mathrm{CH}_{2} \mathrm{NNp}\right)_{3}\right\}\right.$ $\mathrm{W}(\mu-\mathrm{Sb})]$ have shown, ${ }^{[14]}$ the three-centre bond of the W-E-W $\pi$ system $\left(d_{x z}, d_{y z}\right.$ orbitals of both $W$ atoms and the $\mathrm{p}_{\mathrm{x}}, \mathrm{p}_{\mathrm{y}}$ orbitals of the $\mathrm{P}$ atom) of these neutral complexes possess a $\left(1 \pi_{u}\right)^{4}\left(1 \pi_{g}\right)^{3}$ electron configuration with one unpaired electron. According to a formal charge count $\left(2 \times\right.$ "tren" $\left.{ }^{\prime-}, \mathrm{P}^{3-}\right)$ complexes 5-7 represent mixed valent $\mathrm{W}^{\mathrm{IV}} / \mathrm{W}^{\mathrm{v}}$ species.

The low yield of the starting material $\mathbf{3}$ prevents a large scale synthesis of 5-7; this prevents extensive investigations, for example, of their redox properties. Attempts to obtain cyclic voltammograms of any of theses complexes were frustrated by the highly absorptive nature of these species leading to ill-shaped broad waves and the wholly irreversible behaviour following electron transfer. The arsenic complex 6 undergoes an irreversible oxidation at $+0.12 \mathrm{~V}$ versus the ferrocene/ferrocenium couple. The considerable breadth of this wave does not allow any safe conclusion as to the number of electrons transferred in this step. During the reverse scan, an associated composite wave with distinct peaks at -2.08 and $-2.33 \mathrm{~V}$ was observed. At more anodic potentials another irreversible oxidation was found at a peak potential of $+0.59 \mathrm{~V}\left(\mathbf{v}=0.1 \mathrm{Vs}^{\mathrm{m}+1}\right)$. The reduction of $\mathbf{6}$ occurs as an irreversible feature at the very negative potential of $-3.46 \mathrm{~V}$, 
close to the discharge limit of the electrolyte solution. A distinct shoulder at $-3.32 \mathrm{~V}$ was also detected. Similar observations were made for the Sb-bridged complex 7. In light of these results, it is no surprise that our attempts to generate the cationic complex $\left[\left\{\left[\mathrm{N}\left(\mathrm{CH}_{2} \mathrm{CH}_{2} \mathrm{NiPr}\right)_{3}\right] \mathrm{W}\right]_{2} \mathrm{P}\right]^{+}$by treatment of compound 5 with $\left[\mathrm{Cp}_{2} \mathrm{Fe}\right]^{+}\left[\mathrm{BF}_{4}\right]^{-}$were met with failure. This underlines the high kinetic stability of this class of complexes achieved by the bulky $i \operatorname{Pr}$ groups protecting the $(\mathrm{W}=\mathrm{E}=\mathrm{W}$ ) core (Figure 3). In contrast, if the complex $\left[\left\{\mathrm{Cp}^{\prime}(\mathrm{CO})_{2} \mathrm{Mn}\right\}_{2}(\mu-\mathrm{As})\right]^{+}\left(\mathrm{Cp}^{\prime}=\eta^{5}-\mathrm{C}_{5} \mathrm{H}_{4} \mathrm{Me}\right)$ is reduced by $\mathrm{Cp}_{2} \mathrm{Co}$, the diarsenidene complex $\left[\left\{\mathrm{Cp} *(\mathrm{CO})_{2} \mathrm{Mn}\right\}_{2}(\mu-\mathrm{As})\right]_{2}$ is obtained instead of the neutral complex. ${ }^{[10 \mathrm{c}]}$

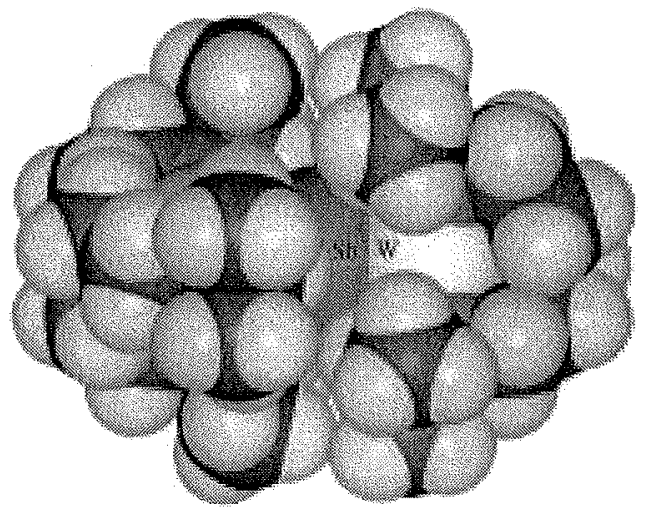

Figure 3. Space-filling model of 7 .

Crystal structure analysis: Compounds 5-7 are isostructural and crystallise in the orthorhombic space group Cmca. The molecules exhibit a mirror plane within the E-W-N(2) axis and an inversion centre in $\mathrm{E}$ leading to a linear axis N-W-EW-N. Therefore, two W-"tren" units bind to a central pnictido atom in a staggered configuration. Figure 4 shows the molecular structure of arsenido complex $\mathbf{6}$ as one example of these compounds. Table 1 contains selected bond lengths and angles showing almost identical values for these complexes. The $\mathrm{W}-\mathrm{N}_{\mathrm{ax}}$ bond lengths decrease from 5 to 7 and are considerably shorter than in the terminal phosphido and

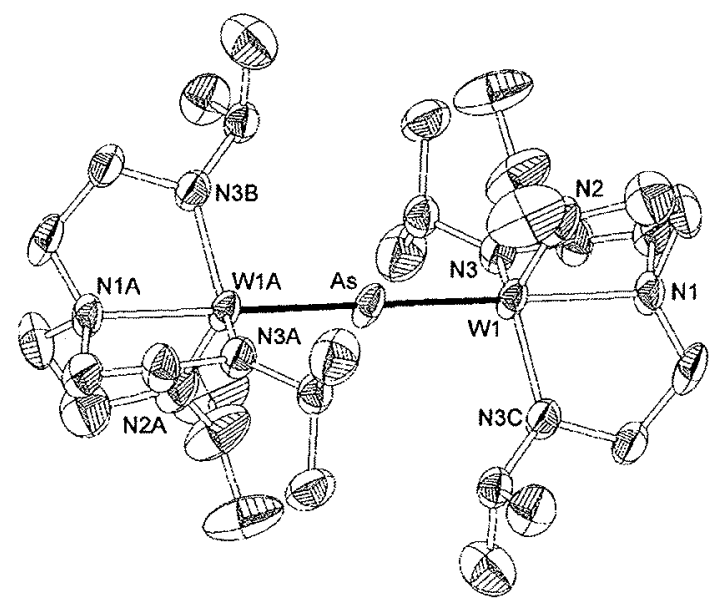

Figure 4. Molecular structure of 6 (ellipsoids drawn at of $50 \%$ probability level).
Table 1. Comparison of selected bond lengths $[\AA]$ and angles $\left[{ }^{\circ}\right]$ of 5-7 $\left(\mathrm{N}_{\mathrm{ax}}: \mathrm{N} 1 ; \mathrm{N}_{\mathrm{eq}}: \mathrm{N} 2, \mathrm{~N} 3\right)$.

\begin{tabular}{lccc}
\hline & $\mathbf{5}$ & $\mathbf{6}$ & $\mathbf{7}$ \\
\hline $\mathrm{W}-\mathrm{E}$ & $2.2331(4)$ & $2.3331(5)$ & $2.5275(5)$ \\
$\mathrm{W}-\mathrm{N}_{\mathrm{cq}}$ & $1.972(6)$ & $1.964(8)$ & $1.986(9)$ \\
& $1.988(4)$ & $1.982(4)$ & $1.989(5)$ \\
$\mathrm{W}-\mathrm{N}_{\mathrm{ax}}$ & $2.246(5)$ & $2.239(9)$ & $2.224(6)$ \\
$\mathrm{W}-\mathrm{E}-\mathrm{W}$ & 180.0 & 180.0 & 180.0 \\
$\mathrm{E}-\mathrm{W}-\mathrm{N}_{\mathrm{ax}}$ & $179.5(1)$ & $179.4(2)$ & $178.4(2)$ \\
$\mathrm{N}_{\mathrm{ax}}-\mathrm{W}-\mathrm{N}_{\mathrm{cq}}$ & $79.7(2)$ & $79.5(2)$ & $79.6(3)$ \\
& $79.5(1)$ & $79.7(1)$ & $79.6(1)$ \\
$\mathrm{N}_{\mathrm{eq}}-\mathrm{W}-\mathrm{N}_{\mathrm{eq}}$ & $115.8(1)$ & $115.9(1)$ & $116.0(2)$ \\
& $118.7(2)$ & $118.7(3)$ & $118.4(3)$ \\
\hline
\end{tabular}

arsenido tungsten complexes $\mathbf{1}$ and $\mathbf{2}$. The distortion of the trigonal-bipyramidal ligand sphere at the central $\mathrm{W}$ atom in 5-7 is also smaller than in $\mathbf{1}$ and $\mathbf{2}$. The $\mathrm{W}$ atom is located out of the plane of the equatorial $\mathrm{N}$ atoms by $0.358 \AA$ on average (1: $0.409 \AA$; 2: $0.417 \AA$ ).

The W-P bond length in $\left[\left\{\left[\mathrm{N}\left(\mathrm{CH}_{2} \mathrm{CH}_{2} \mathrm{NiPr}\right)_{3}\right] \mathrm{W}\right\}_{2}(\mu-\mathrm{P})\right](\mathbf{5})$ is 2.2331(4) $\AA$ and longer than the $\mathrm{W} \equiv \mathrm{P}$ triple-bond length in $1 \quad[2.162(4) \AA]^{[4]}, \quad\left[\left(\mathrm{N}_{3} \mathrm{~N}\right) \mathrm{W} \equiv \mathrm{P} \rightarrow \mathrm{W}(\mathrm{CO})_{4} \leftarrow \mathrm{P} \equiv \mathrm{W}\left(\mathrm{N}_{3} \mathrm{~N}\right)\right]$ $(2.202(2) \AA)^{[5]}$ and $\left[\left(\mathrm{N}_{3} \mathrm{~N}\right) \mathrm{W} \equiv \mathrm{P} \rightarrow \mathrm{GaCl}_{3}\right] \quad(2.168(4) \AA)^{[7]}$ $\left[\mathrm{N}_{3} \mathrm{~N}=\mathrm{N}\left(\mathrm{CH}_{2} \mathrm{CH}_{2} \mathrm{NSiMe}_{3}\right)_{3}\right]$. Metal-phosphorus multiple bonds containing a phosphinidene ligand $\left(\mathrm{L}_{\mathrm{n}} \mathrm{M}=\mathrm{PR}\right)$ in a linear arrangement (M-P-R: $\left.180^{\circ}\right)$ also reveal triple-bond character. For example, in $\left[\left(\mathrm{Ph}_{2} \mathrm{MeP}\right) \mathrm{Cl}_{2}(\mathrm{CO}) \mathrm{W}=\mathrm{PR}\right](\mathrm{R}=$ 2,4,6-tBu $\left.u_{3} \mathrm{C}_{6} \mathrm{H}_{2}\right)$ the $\mathrm{W}-\mathrm{P}$ distance is 2.169(1) $\AA^{\left[{ }^{[18]}\right.}$ In the bent phosphinidene complexes, in which the lone pair is located at the $\mathrm{P}$ atom, the $\mathrm{W}-\mathrm{P}$ bond corresponds to a double bond; for example, in $\left[\mathrm{Cp}_{2} \mathrm{~W}=\mathrm{PR}\right]\left(\mathrm{R}=2,4,6-t B u_{3} \mathrm{C}_{6} \mathrm{H}_{2}\right)^{[19]}$ this bond is 2.349(5) $\AA$ and therefore, considerably longer than that found in 5.

In $\left[\left\{\left[\mathrm{N}\left(\mathrm{CH}_{2} \mathrm{CH}_{2} \mathrm{NiPr}\right)_{3}\right] \mathrm{W}\right\}_{2}(\mu\right.$-As) $)(6)$ the $\mathrm{W}-\mathrm{As}$ bond length is 2.3331(5) $\AA$ and is longer than that found in $\left[\left\{\mathrm{N}\left(\mathrm{CH}_{2} \mathrm{CH}_{2} \mathrm{NSiMe}_{3}\right)_{3}\right\} \mathrm{W} \equiv \mathrm{As}\right](2)[2.290(1) \AA] .^{[5]}$ The only known complex with a linear $(\mu$-As) bridge is the cationic complex $\left[\left\{\mathrm{Cp} *(\mathrm{CO})_{2} \mathrm{Mn}\right\}_{2}(\mu \text {-As })\right]^{+},{ }^{[10 a]}$ which has $\mathrm{Mn}-\mathrm{As}$ bond lengths of 2.142(2) and 2.151(2) $\AA$.

The W-Sb bond length in $\left[\left\{\left[\mathrm{N}\left(\mathrm{CH}_{2} \mathrm{CH}_{2} \mathrm{~N} i \mathrm{Pr}\right)_{3}\right] \mathrm{W}\right\}_{2}(\mu-\mathrm{Sb})\right]$ (7) is $2.5275(5) \AA$ and is the shortest known $\mathrm{W}-\mathrm{Sb}$ bond length. Other short $\mathrm{W}-\mathrm{Sb}$ bond lengths were found in the isostructural complex $\left[\left\{\left[\mathrm{N}\left(\mathrm{CH}_{2} \mathrm{CH}_{2} \mathrm{NNp}\right)_{3}\right] \mathrm{W}\right\}_{2}(\mu-\mathrm{Sb})\right]^{[14]}$ with $2.5738(8) \AA$ and in the bent compound $\left[\left\{(\mathrm{CO})_{5} \mathrm{~W}\right\}_{2} \mathrm{SbCl}(\right.$ thf $\left.)\right]$ with 2.662(1) and 2.670(2) $\AA{ }^{.}{ }^{(20)}$ In the latter complex the lone pair at the $\mathrm{Sb}$ atom is delocalised within a $\pi$ system that possesses a bond order larger than one. Besides 7 and its Npsubstituted analogue, the only other example with a linear $\mu$-Sb bridge is the cationic complex $\left[\left\{\left(\eta^{6}-\mathrm{C}_{6} \mathrm{Me}_{6}\right)(\mathrm{CO})_{2} \mathrm{Cr}\right\}_{2^{-}}\right.$ $(\mu-\mathrm{Sb})]^{+}$with $\mathrm{Cr}--$ Sb bond lengths of 2.378(2) and 2.396(2) $\AA . .^{(10 \mathrm{~d}]}$

\section{Conclusion}

The reaction behaviour between $\left[\left\{\mathrm{N}\left(\mathrm{CH}_{2} \mathrm{CH}_{2} \mathrm{NR}\right)_{3}\right\} \mathrm{WCl}\right]$ and $\left[\mathrm{LiE}\left(\mathrm{SiMe}_{3}\right)_{2}\right](\mathrm{E}=\mathrm{P}, \mathrm{As}, \mathrm{Sb}, \mathrm{Bi})$ is very sensitive to the nature of the group $\mathrm{R}$ as well as the pnictogen atom $\mathrm{E}$. If $\mathrm{R}$ is bulky, as in the case of the $\mathrm{SiMe}_{3}$ group, complexes with terminal pnictido ligands are obtained for $\mathrm{E}=\mathrm{P}$ and $\mathrm{As}$, whereas for 
$\mathrm{E}=\mathrm{Sb}$ and $\mathrm{Bi}$ no reaction occurs. The reduction of the steric demand of the R group at the "tren" ligand, by using Np or $i \mathrm{Pr}$ groups as $\mathrm{R}$, leads to novel neutral $\mu$-E-bridged complexes. Although so far the isolation of the corresponding $\mathrm{Bi}$ complex failed, the protocol presented herein provides a general synthetic route for the entire series of the heavier Group 15 elements. The space-filling model of 7 (Figure 3 ) reveals that the $i \operatorname{Pr}$ groups of the opposite "tren" ligands are staggered with respect ot each other and, hence, enable the formation of the $\mu$-E-bridged heterocumulene. Only with the introduction of appropriate R groups in the "tren" system, which provides a larger cavity around the central $\mathrm{W}$ atom and at the same time hinders the dimerisation to form heterocumulenes, should the goal of obtaining complexes with terminal pnictido ligands of antimony and bismuth be achieved. These investigations are in progress.

\section{Experimental Section}

General techniques: All reactions were performed under an atmosphere of dry argon by using Schlenk techniques. Solvents were purified and degassed by standard procedures. NMR spectra were recorded on a Bruker AC250 [ ${ }^{1} \mathrm{H}: 250.13 \mathrm{MHz} ;{ }^{31} \mathrm{P}: 101.256 \mathrm{MHz}$; standard $\mathrm{Me}_{4} \mathrm{Si}\left({ }^{1} \mathrm{H}\right)$ $\left.85 \% \mathrm{H}_{3} \mathrm{PO}_{4}\left({ }^{31} \mathrm{P}\right)\right]$. MS: Finnigan MAT711 at $70 \mathrm{eV}$ and $180^{\circ} \mathrm{C}$. Elementa analyses were performed by the analytical laboratory of the institute. Electrochemistry: experiments were carried out under argon in a cylindrical one-compartment cell equipped with two sidearms that were connected to a conventional Schlenk line. The Pt counter and the $\mathrm{Ag}$ reference electrode were welded into the glass wall, while the working electrode was introduced through a screwcap with a suitable fitting. Al experiments were performed in $\mathrm{THF} / \mathrm{NBu}_{4} \mathrm{PF}_{6}$ electrolyte with an EG\& G273 potentiostat.

Reagents: Unless otherwise stated, commercial-grade chemicals were used without further purification. $\mathrm{Li}\left[\mathrm{P}\left(\mathrm{SiMe}_{3}\right)_{2}(\mathrm{thf})_{n}\right]$ and $\mathrm{Li}\left[\mathrm{E}\left(\mathrm{SiMe}_{3}\right)_{2}(\mathrm{dme})_{n}\right]$
$(\mathrm{E}=\mathrm{As}, \mathrm{Sb}, \mathrm{Bi})$ were prepared as described in ref.[21] and $\mathrm{N}\left(\mathrm{CH}_{2} \mathrm{CH}_{2} \mathrm{~N}(\mathrm{H}) i \mathrm{Pr}\right)_{3}$ as in ref. [21].

Preparation of $\left[\left(\mathbf{N}\left(\mathrm{CH}_{2} \mathrm{CH}_{2} \mathrm{NiPr}\right)_{3}\right] \mathrm{WCl}\right]$ (3). $\mathrm{Li}_{3}\left[\mathrm{~N}\left(\mathrm{CH}_{2} \mathrm{CH}_{2} \mathrm{NiPr}\right)_{3}\right.$ $\left(24 \mathrm{mmol}\right.$ )-synthesised from $\mathrm{N}\left(\mathrm{CH}_{2} \mathrm{CH}_{2} \mathrm{~N}(\mathrm{H}) i \mathrm{Pr}\right)_{3}$ by addition of three equivalents of $n \mathrm{BuLi}$-were added portionwise to a suspension of $\left[\mathrm{WCl}_{4}(\mathrm{dme})\right](10 \mathrm{~g}, 24 \mathrm{mmol})$ in THF $(250 \mathrm{~mL})$ over a period of $2 \mathrm{~h}$ at $-40^{\circ} \mathrm{C}$. After warming to ambient temperature the mixture was stirred for further $12 \mathrm{~h}$. The solvent was removed in vacuo $\left(10^{-3} \mathrm{Torr}\right)$ and the residue was extracted with boiling $n$-hexane $(50 \mathrm{~mL})$. After removing all of the solvent, the residue was recrystallised from toluene. At $5^{\circ} \mathrm{C}, 1.17 \mathrm{~g}(10 \%)$ of 3 were obtained. ${ }^{1} \mathrm{H}$ NMR $\left(250.13 \mathrm{MHz}, 25^{\circ} \mathrm{C}, \mathrm{C}_{6} \mathrm{D}_{6}\right): \delta=25.2(\mathrm{~s}, 18 \mathrm{H}$ $\left.\mathrm{CH}_{3}\right),-0.6(\mathrm{~b}, 3 \mathrm{H}, \mathrm{CH}),-22.9\left(\mathrm{~b}, 6 \mathrm{H}, \mathrm{CH}_{2}\right),-62.7\left(\mathrm{~b}, 6 \mathrm{H}, \mathrm{CH}_{2}\right)$; EI MS $\mathrm{m} / \mathrm{z}(\%): 488(40)[M]^{+}, 445(100)\left[M-\mathrm{C}_{3} \mathrm{H}_{7}\right]^{+}$.

Synthesis of $\left[\left[\left[\mathrm{N}\left(\mathrm{CH}_{2} \mathrm{CH}_{2} \mathrm{~N} i \mathrm{Pr}\right)_{3}\right] \mathrm{W}\right]_{2}(\mu-\mathrm{E})\right][\mathrm{E}=\mathrm{P}$ (5), As (6), Sb (7)]: Complex $3(100 \mathrm{mg}, 0.2 \mathrm{mmol})$ and $\mathrm{Li}\left[\mathrm{P}\left(\mathrm{SiMe}_{3}\right)_{2}(\mathrm{thf})_{n}\right]$ or $\mathrm{Li}\left[\mathrm{E}\left(\mathrm{SiMe}_{3}\right)_{2}(\mathrm{~d}\right.$ $\left.\mathrm{me})_{n}\right](\mathrm{E}=\mathrm{As}, \mathrm{Sb})(0.4 \mathrm{mmol})$ were dissolved in toluene $(15 \mathrm{~mL})$ and stirred at $100^{\circ} \mathrm{C}$ for $48 \mathrm{~h}$ under light exclusion. Subsequently, the solution was filtered over silica gel. The filtrate and the washing solution were combined and reduced to $5 \mathrm{~mL}$. At $-20^{\circ} \mathrm{C}, 60 \mathrm{mg}(32 \%)$ of $5,85 \mathrm{mg}$ ( $43 \%)$ of 6 and $62 \mathrm{mg} \mathrm{(30 \% )} \mathrm{of} 7$ could be isolated in crystalline form. Compund 5: ${ }^{1} \mathrm{H}$ NMR $\left(250.13 \mathrm{MHz}, 25^{\circ} \mathrm{C}, \mathrm{C}_{6} \mathrm{D}_{6}\right): \delta=23.0\left(\mathrm{~b}, 6 \mathrm{H}, \mathrm{CH}_{2}\right)$, $-4.52\left(\mathrm{~b}, 18 \mathrm{H}, \mathrm{CH}_{3}\right),-12.7$ (b, 6H, $\left.\mathrm{CH}_{2}\right)$; EI MS: $m / z(\%): 938(100)[\mathrm{M}]^{+}$, $484(20)\left[\left[\mathrm{N}\left(\mathrm{CH}_{2} \mathrm{CH}_{2} \mathrm{NiPr}\right)_{3}\right] \mathrm{WP}\right]^{+} ; \mu_{\mathrm{eff}}\left(\right.$ Evan's method, $\left.\mathrm{C}_{6} \mathrm{D}_{8}, 300 \mathrm{~K}\right)=$ $2.00 \mu_{B}$.

Compound 6: ${ }^{1} \mathrm{H}$ NMR $\left(250.13 \mathrm{MHz}, 25^{\circ} \mathrm{C}, \mathrm{C}_{6} \mathrm{D}_{6}\right): \delta=22.7\left(\mathrm{~b}, 6 \mathrm{H}, \mathrm{CH}_{2}\right)$, $-4.12\left(\mathrm{~b}, 18 \mathrm{H}, \mathrm{CH}_{3}\right),-13.7\left(\mathrm{~b}, 6 \mathrm{H}, \mathrm{CH}_{2}\right)$; EI MS: $\mathrm{m} / z(\%): 982(100)[\mathrm{M}] *$, 528 (59) $\left[\left[\mathrm{N}\left(\mathrm{CH}_{2} \mathrm{CH}_{2} \mathrm{NiPr}\right)_{3}\right] \text { WAs }\right]^{4} ; \mu_{\text {eff }}$ (Evan's method, $\left.\mathrm{C}_{6} \mathrm{D}_{8}, 300 \mathrm{~K}\right)=$ $2.02 \mu_{B}$; elemental analysis calcd (\%) for $\mathrm{C}_{30} \mathrm{H}_{66} \mathrm{~N}_{8} \mathrm{AsW}_{2}$ (981.53): C 36.71 H 6.78, N 11.42; found C 36.35, H 6.50, N 11.08.

Compound 7: ${ }^{1} \mathrm{H}$ NMR $\left(250.13 \mathrm{MHz}, 25^{\circ} \mathrm{C}, \mathrm{C}_{6} \mathrm{D}_{6}\right): \delta=22.2\left(\mathrm{~b}, 6 \mathrm{H}, \mathrm{CH}_{2}\right)$ -3.82 (b, 18H, $\mathrm{CH}_{3}$ ), - 14.2 (b, 6H, $\mathrm{CH}_{2}$ ); EI MS: $m / z$ (\%): 1027 (41) [M]-, 574 (95) $\left[\left\{\mathrm{N}\left(\mathrm{CH}_{2} \mathrm{CH}_{2} \mathrm{NiPr}\right)_{3}\right\} \mathrm{WSb}\right]^{+}, 409(100)\left[\mathrm{WN}_{4} \mathrm{C}_{12} \mathrm{H}_{25}\right]^{+} ; \mu_{\text {eff }}$ (Evan's method, $\left.\mathrm{C}_{6} \mathrm{D}_{8}, 300 \mathrm{~K}\right)=2.04 \mu_{\mathrm{B}}$; elemental analysis calcd (\%) for $\mathrm{C}_{30} \mathrm{H}_{66} \mathrm{~N}_{8} \mathrm{SbW}_{2}$ (1028.36): C 35.04, H 6.47, N 10.90; found C 34.75, H 6.02, N 10.67 .

Crystal structure analyses of 3-7: Crystal structure analyses were performed on a STOE STADI IV (3, 5-7: $w$-scan mode) and a STOE IPDS (4) diffractometer with $\mathrm{Mo}_{\mathrm{K} \alpha}$ radiation $(\lambda=0.71073 \AA)$ with empiri-

Table 2. Crystallographic data for 3-7.

\begin{tabular}{|c|c|c|c|c|c|}
\hline & 3 & 4 & 5 & 6 & 7 \\
\hline formula & $\mathrm{C}_{15} \mathrm{H}_{33} \mathrm{ClN}_{4} \mathrm{~W}$ & $\mathrm{C}_{42} \mathrm{H}_{90} \mathrm{~N}_{10} \cdot \mathrm{W}_{2}$ & $\mathrm{C}_{30} \mathrm{H}_{66} \mathrm{~N}_{8} \mathrm{PW}_{2}$ & $\mathrm{C}_{30} \mathrm{H}_{66} \mathrm{~N}_{8} \mathrm{AsW}_{2}$ & $\mathrm{C}_{30} \mathrm{H}_{66} \mathrm{~N}_{8} \mathrm{SbW}_{2}$ \\
\hline$M_{\mathrm{w}}$ & 488.75 & 1102.94 & 937.58 & 981.53 & 1028.36 \\
\hline crystal size [mm] & $0.76 \times 0.27 \times 0.27$ & $0.27 \times 0.15 \times 0.04$ & $0.38 \times 0.20 \times 0.08$ & $0.57 \times 0.19 \times 0.08$ & $0.34 \times 0.34 \times 0.08$ \\
\hline$T[\mathrm{~K}]$ & $200(2)$ & $200(1)$ & $200(2)$ & $200(2)$ & $200(2)$ \\
\hline space group & $P_{1} / c$ (No. 14$)$ & $R \overline{3}$ (No. 148 ) & Cmca (No. 64) & Cmca (No. 64) & Cmca (No. 64) \\
\hline crystal system & monoclinic & trigonạl & orthorhombic & orthorhombic & orthorhombic \\
\hline$a[\AA]$ & $12.059(2)$ & $16.475(2)$ & $16.109(3)$ & $16.008(3)$ & $15.955(3)$ \\
\hline$b[\AA ̊]$ & $10.055(2)$ & $16.475(2)$ & $12.291(3)$ & $12.116(2)$ & $12.180(2)$ \\
\hline$c[\AA]$ & $16.069(3)$ & $15.477(3)$ & $19.018(4)$ & $19.350(4)$ & $20.165(4)$ \\
\hline$\alpha\left[^{\circ}\right]$ & 90 & 90 & 90 & 90 & 90 \\
\hline$\beta\left[^{\circ}\right]$ & $91.69(3)$ & 90 & 90 & 90 & 90 \\
\hline$\gamma\left[^{\circ}\right]$ & 90 & 120 & 90 & 90 & 90 \\
\hline$V\left[\AA^{3}\right]$ & $1947.6(7)$ & $3638.0(10)$ & $3765.5(13)$ & $3768.4(13)$ & $3918.7(13)$ \\
\hline$Z$ & 4 & 3 & 4 & 4 & 4 \\
\hline$\rho_{\text {calod }}\left[\mathrm{g} \mathrm{cm}^{-3}\right]$ & 1.667 & 1.510 & 1.654 & 1.730 & 1.743 \\
\hline$\mu\left[\mathrm{mm}^{-1}\right]$ & 6.069 & 4.777 & 6.177 & 7.002 & 6.570 \\
\hline $2 \theta$ range $\left[{ }^{\circ}\right]$ & $3.38 \leq 2 \theta \leq 56$ & $3.88 \leq 2 \theta \leq 52.32$ & $4.28 \leq 2 \theta \leq 54.98$ & $4.20 \leq 2 \theta \leq 52.10$ & $4.04 \leq 2 \theta \leq 55.06$ \\
\hline \multirow[t]{3}{*}{$h k l$ range } & $-14 \leq h \leq 14$ & $-20 \leq h \leq 20$ & $0 \leq h \leq 20$ & $-11 \leq h \leq 19$ & $0 \leq h \leq 20$ \\
\hline & $0 \leq k \leq 12$ & $-18 \leq k \leq 20$ & $0 \leq k \leq 15$ & $-11 \leq k \leq 14$ & $0 \leq k \leq 15$ \\
\hline & $-0 \leq l \leq 19$ & $-19 \leq l \leq 18$ & $-24 \leq l \leq 0$ & $0 \leq l \leq 23$ & $-26 \leq l \leq 0$ \\
\hline data/restrains/parameters & $3807 / 0 / 193$ & $1605 / 0 / 143$ & $2227 / 0 / 119$ & $1932 / 0 / 119$ & $2337 / 0 / 129$ \\
\hline independent reflections $[I>2 \sigma(I)]$ & $3549\left(R_{\mathrm{int}}=0.000\right)$ & $1558\left(R_{\text {int }}=0.0657\right)$ & $1994\left(R_{\mathrm{int}}=0.000\right)$ & $1656\left(R_{\text {int }}=0.0364\right)$ & $2023\left(R_{\text {int }}=0.000\right)$ \\
\hline goodness-of-fit on $F^{2}$ & 1.223 & 1.091 & 1.137 & 1.009 & 1.099 \\
\hline$R_{1},{ }^{[\mathrm{a}]} w R_{2}^{[\mathrm{b}]}[I>2 \sigma(I)]$ & $0.0498,0.1504$ & $0.0425,0.0960$ & $0.0288,0.0700$ & $0.0280,0.0649$ & $0.0333,0.0764$ \\
\hline$R_{1},{ }^{\text {[a] }} w R_{2}{ }^{(\mathrm{b}]}$ [all data] & $0.0548,0.1781$ & $0.0454,0.0996$ & $0.0350,0.0767$ & $0.0383,0.0719$ & $0.0429,0.0864$ \\
\hline largest diff. peak/hole $\left[\mathrm{e} \AA^{-3}\right.$ ] & $4.664 /-2.209$ & $2.937 /-1.574$ & $1.219 /-2.093$ & $0.667 /-1.434$ & $1.367 /-1.875$ \\
\hline
\end{tabular}

[a] $R=\Sigma\left|F_{0}\right|-\left|F_{\mathrm{c}}\right| / \Sigma\left|F_{0}\right| \cdot[\mathrm{b}] w R_{2}=\left[\Sigma>\mathrm{w}\left(F_{\mathrm{o}}^{2}-F_{\mathrm{c}}^{2}\right)^{2}\right] /\left[\Sigma\left(F_{\mathrm{o}}^{2}\right)^{2}\right]^{1 / 2}$ 
cal absorption corrections for 3,5-7 (Psi scans). The structures were solved by direct methods by using SHELXS-86, ${ }^{12}$

refinement on $F^{2}$ in SHELXL-93 ${ }^{[23 b]}$ with anisotropic displacement for nonhydrogen atoms; hydrogen atoms were located in idealized positions and refined isotropically according to the riding model. In 3 and 5-7 the $\mathrm{CH}_{2}$ groups attached to the $\mathrm{N}_{\mathrm{ax}}$ atom of the tris-(2-amidoethyl)amine-ligands are disordered; in 7 the $\mathrm{CH}_{3}$ groups of the isopropyl substituents on the $\mathrm{N}(2)$ atom are disordered in addition. Crystallographic data for compounds 3-7 are given in Table 2 .

Crystallographic data (excluding structure factors) for the structures reported in this paper have been deposited with the Cambridge Crystallographic Data Centre as supplementary publication no. CCDC 129224 CCDC 129228. Copies of the data can be obtained free of charge on application to CCDC, 12 Union Road, Cambridge CB21EZ, UK (fax: (+44) 1223-336-033; e-mail: deposit@ccdc.cam.ac.uk).

\section{Acknowledgement}

We are grateful to the Deutsche Forschungsgemeinschaft and the Fonds de Chemischen Industrie (FCI) for comprehensive financial support of our work. M. Schiffer thanks the FCI for a PhD fellowship. The authors thank Prof. Dr. R. Kirmse, University of Leipzig, for carrying out the EPR measurements.

[1] Reviews: a) M. Scheer, E. Herrmann, Z. Chem. 1990, 30, 41-55; b) O. J. Scherer, Angew. Chem. 1990, 102, 1137-1155; Angew. Chem. Int. Ed. Engl. 1990, 29, 1104-1122; c) K. H. Whitmire, Adv. Organomet. Chem. 1998, 42, 1-145.

[2] Reviews: a) M. Scheer, Angew. Chem. 1995, 107, 2151 -2153; Angew. Chem. Int. Ed. Engl. 1995, 34, 1997-1999; b) M. Scheer, Coord. Chem. Rev. 1997, 163, 271-286.

[3] C. E. Laplaza, W. M. Davis, C. C. Cummins, Angew. Chem. 1995, 107, 2181 -2183; Angew. Chem. Int. Ed. Engl. 1995, 34, 2042-2043.

[4] N. C. Zanetti, R. R. Schrock, W. M. Davis, Angew. Chem. 1995, 107, 2184-2186; Angew. Chem. Int Ed. Engl. 1995, 34, 2044-2046.

[5] M. Scheer, J. Müller, M. Häser, Angew. Chem. 1996, 108, 2637-2641; Angew. Chem. Int. Ed. Engl. 1996, 35, 2492-2496.

[6] N. C. Zanetti, R. R. Schrock, W. M. Davis, K. Wanninger, S. W. Seidel, M. B. O'Donoghue, J. Am. Chem. Soc. 1997, 119, 11037-11048.

[7] M. Scheer, J. Müller, G. Baum, M. Häser, Chem. Commun. 1998, $1051-1052$

[8] M. Scheer, P. Kramkowski, K. Schuster, Organometallics 1999, 18, $2874-2883$.

[9] P. Kramkowski, G. Baum, U. Radius, M. Kaupp, M. Scheer, Chem. Eur. J 1999, 5, 2890-2898.
[10] a) A. Strube, G. Huttner, L. Zsolnai, Angew. Chem. 1988, I00, $1586-$ 1587; Angew. Chem. Int. Ed. Engl. 1988, 27, 1529; b) A. Strube, J. Heuser, G. Huttner, H. Lang, J. Organomet. Chem. 1988, 356, C9C11; c) A. Strube, G. Huttner, L. Zsolnai, J. Organomet. Chem. 1990 399, 267-279; d) F. Bringewski, G. Huttner, W. Imhof, J. Organomet. Chem. 1993, 448, C3 - C5; e) S. J. Davies, N. A. Compton, G. Huttner, L. Zolnai, S. E. Garner, Chem. Ber. 1991, 124, $2731-2738$.

[11] M. C. Fermin, J. Ho, D. W. Stephan, Organometallics 1995, 14, 4247 4256.

[12] M. J. A. Johnson, P. M. Lee, A. L. Odom, W. M. Davis, C. C. Cummins, Angew. Chem. 1997, 109, 110-113; Angew. Chem. Int. Ed. Engl. 1997, 36, 87-91.

[13] For reviews see: a) K. Dehnicke, J. Strähle, Angew. Chem. 1981, 93 , 451-464; Angew. Chem. Int. Ed. Engl. 1981, 20, 413-426; b) K. Dehnicke, J. Strähle, Angew. Chem. 1992, 104, 978-1000; Angew. Chem. Int. Ed. Engl. 1992, 32, 955-978; c) W. A. Herrmann, Angew. Chem. 1986, 98, 57-77; Angew. Chem. Int. Ed. Engl. 1986, 25, 56-76; d) P. Kramkowski, M. Scheer, Angew. Chem. 2000, 112, 959-962; Angew. Chem. Int. Ed. 2000, 39, 928-931.

[14] M. Scheer, J. Müller, G. Baum, M. Häser, Chem. Commun. 1998, 2505-2606.

[15] M. Hidai, Y. Mizobe, Chem. Rev. 1995, 95, 1115-1133.

[16] K. Shih, R. R. Schrock, R Kempe, J. Am. Chem. Soc. 1994, 116, 8804 8805 .

[17] 'H NMR ([D ${ }^{\prime}$ toluene): $\delta=23.5\left(\mathrm{~b}, \mathrm{CH}_{2}\right),-6.9\left(\mathrm{~b}, \mathrm{CH}_{3}\right),-12.3(\mathrm{~b}$ $\mathrm{CH}_{2}$ ).

[18] A. H. Cowley, B. Pellerin, J. L. Atwood, S. G. Bott, J. Am. Chem. Soc 1990, 112, 6734-6735.

[19] P. Bohra, P. B. Hitchcock, M. F. Lappert, W. P. Leung, Polyhedron 1989, 8, 1884.

[20] M. Schiffer, Diplom Thesis, University of Karlsruhe, 1997.

[21] a) G. Becker, H. Schmidt, W. Uhl, Inorg. Synth. 1990, 27, 243; b) G. Becker, A. Münch, C. Witthauer, Z. Anorg. Allg. Chem. 1982, 492, 15-27; c) G. Becker, C. Witthauer, Z. Anorg. Allg. Chem. 1982, 492, 28 -36; d) O. Mundt, G. Becker, M. Rössler, C. Witthauer, Z. Anorg. Allg. Chem. 1983, 506, 42-58; e) G. Becker, H. Freudenblum, O. Mundt, M. Reti, M. Sachs, in Synthetic Methods of Organometallic and Inorganic Chemistry, Vol. 3 (Ed. W. A. Herrmann, H. H. Karsch), Thieme, Stuttgart, 1996, pp. 193-198.

[22] L. H. Gade, N. Mahr, J. Chem. Soc. Dalton Trans. 1993, 489-494.

[23] a) G. M. Sheldrick, SHELXS-86, Program for Crystal Structure Determinations, University of Göttingen, 1986; b) G. M. Sheldrick, SHELXL-93, Program for Crystal Structure Refinement, University of Göttingen, 1993. 